\title{
Eye Lymphoma
}

National Cancer Institute

\section{Source}

National Cancer Institute. Eye Lymphoma. NCI Thesaurus. Code C35690.

A lymphoma involving the eye. 